\title{
A Nation Beyond Its Borders
}

In the books of Deuteronomy and Joshua, the NTT resumes at key moments, raising a basic question: Why would Judean scribes, during the postexilic period, go to the trouble of expanding the Pentateuch and book of Joshua with memories of the Transjordanian tribes? Critical interpreters of these texts typically claim that the scribes were attempting to explain how Israelite communities came to occupy territories in the Transjordan and that these scribes were working under the assumption that solely Canaan was the Promised Land. This formalistic explanation may be valid, but it's incomplete: it does not take into account the real-life political issues posed by the Transjordanian communities, and it fails to do justice to the complexity and nuances in these texts.

As we will continue to see, the NTT is engaged in a battle over the identity of important communities that reside in territories that many considered to be outside Israel's homeland. The status of these communities was a highly contentious matter, and for this reason the first episode of the NTT consists of unusually prolix exchanges: by depicting an enraged and hostile Moses hurling sharp invectives at the tribes of Reuben and Gad, Numbers 32 provides a literary occasion for these eastern communities to repudiate accusations against them and affirm, in a thorough and eloquent manner, the allegiance that motivated the decision of their ancestors to take up residence in the Transjordan.

In the present chapter, we examine how the NTT wends its way through the Hexateuch, culminating in another lengthy episode (Josh. 22) that consists of similar vociferous exchanges between the eastern tribes and the nation's leader. Compared to the opening sequence (Num. 32 ), the final episode goes further by denying the territories occupied by 
the eastern tribes a special, let alone sacred, status. These tribes live beyond Israel's borders, even if their members belong to the nation. The texts that we study in this chapter identify the basis of this national belonging, and in so doing, take on the complex issue of diasporahomeland relations. ${ }^{\mathrm{I}}$

\section{MOSES'S MEMORY IN DEUTERONOMY}

As Israel prepares to cross the Jordan in the book of Deuteronomy, Moses recalls the deal he made with the tribes of Reuben and Gad. He claims that he assigned the Transjordanian territories to the two tribes at the time Israel conquered them (as if Numbers 32 stood in immediate proximity to Numbers 2I). He says nothing about the dispute with these tribes and neglects to mention his directions to Eleazar, Joshua, and the tribal heads. ${ }^{2}$ He also reminds the tribes of their obligation to march as a vanguard for their Israelite kin, not specifically for Yhwh (as in the Priestly editions of Numbers 32):

At that time, I charged you, saying, "Yhwh your god has given you this country to possess. You must go as shock troops, warriors all, in the vanguard of your Israelite brothers. Only your wives, children, and livestock - I know that you have much livestock - shall be left in the towns I have assigned to you, until Yhwh gives your brothers rest such as you have, and they too have taken possession of the land that Yhwh your god is giving them, beyond the Jordan. Then you may return each to the homestead that I have assigned to you." Deut. 3:I 8-20

This paragraph belongs to a section (vv. I 2-20) that retells, at length yet with many modifications, the events from Numbers 32 . The entire section appears to be a supplement. Notice how the reference to "these two kings" in verses $2 \mathrm{I}-22$ forms the direct continuation of verses 8-I I (see also 2:24-3:7). The literary join is severed, however, by the section related to the Transjordanian tribes:

3:8 So at that time we took from the two kings of the Amorites the Transjordanian lands, from the Wadi Arnon to Mount Hermon - 9 the Sidonians call Hermon Sirion, while the Amorites call it Senir - Io all the towns of the tableland, the whole of Gilead, and all of Bashan, as far as Salecah and Edrei, towns of Og's kingdom in

I This observation has been developed recently and forcefully by Rachel Havrelock in River Jordan: The Mythology of a Dividing Line (Chicago: University of Chicago Press, 20 I I).

2 One must bear in mind that throughout his speech, Moses presents himself as the primary instigator and actor in all episodes of Israel's history. It's not surprising, then, that he takes responsibility for the Transjordanians' initiative. 
Bashan. (I I Now only King Og of Bashan was left of the remnant of the Repahim. His bed, an iron bedstead, can still be seen in Rabat of the Ammonites; it is nine cubits long and four cubits wide, by the standard cubit. ${ }^{3}$ )

[vv. I 2-20]

3:2 I And I charged Joshua at that time: "Your own eyes have seen everything that Yhwh your god has done to these two kings; so Yhwh will do to all the kingdoms into which you are about to cross. 22 Do not fear them, for it is Yhwh your god who fights for you."

In verse 2I Moses exhorts Joshua to be fearless, beginning with a reference to Sihon and Og: "Your own eyes have seen everything that Yhwh your god has done to these two kings; so Yhwh will do to all the kingdoms into which you are about to cross." After the lengthy and detailed paragraphs treating the allocation of the Transjordanian lands in verses I 2-2O, the formulation "these two kings" in verse $2 \mathrm{I}$ is too far removed from its antecedent. According to conventional biblical narrative style, we would expect the scribe to have repeated the names "Sihon and Og" after so many verses. Instead, we read "these two kings," and the reason is likely that this line originally stood in close proximity to verse 8 , which it naturally follows.

It seems quite probable, then, that earlier editions of Moses's speech in Deuteronomy I -3 commemorated the conquest and settlement in the Transjordan, but had nothing to say about the Transjordanian tribes. If such is the case, the authors of these first iterations of Moses's speech may not have known Numbers 32, which in turn lends weight to the impression that the remaining references to the Transjordanian tribes are late additions to their contexts (e.g., Deut. 4:4I-43).

At the other end of the book, Moses mentions the Transjordan as he exhorts the nation to remain faithful to the covenant they made with Yhwh. The conquest and settlement of this region is the final of three moments (or stages) in the nation's past when Yhwh performed wondrous feats (the other two being the exodus from Egypt and the wilderness wanderings). If Yhwh has hitherto blessed Israel and granted it victory over its enemies, the nation's future prosperity requires fidelity to the covenant:

When you reached this place, King Sihon of Heshbon and King Og of Bashan came out to engage us in battle, but we defeated them. We took their land and gave it to the Reubenites, the Gadites, and the half-tribe of Manasseh as their heritage.

3 Verse I I represents one of the many anecdotal, (proto-)aggadic glosses in Deut. I-3, and their supplementary character has long been noted in scholarship. 
Therefore, observe faithfully all the terms of this covenant, that you may succeed in all that you undertake. Deut. 29:6-8

The distribution of the eastern territories among the Transjordanian tribes is memorialized here as both an important chapter in the nation's history and concrete historical proof of the covenant's validity. From this point until the final episode in Joshua 22, the NTT will add to Reuben and Gad the half-tribe of Manasseh, which was supplied secondarily to Numbers 32:33-42. Likewise, it will continue to cite Moses's orders to these tribes to cross the Jordan and participate in battle.

\section{AFFIRMING ALLEGIANCE IN JOSHUA}

The composition of the NTT has dramatically shaped the contours of the book of Joshua. In the opening chapter of this book, Joshua addresses the nation on the eve of the invasion, and as he does, he reminds the Transjordanian tribes of their obligation to pass over the Jordan and fight in the vanguard of Israel (in keeping with the older version of Numbers 32). Here, Moses's successor reiterates the instructions he delivered in Deuteronomy 3:18-20, making only slight changes:

Then Joshua said to the Reubenites, the Gadites, and the half-tribe of Manasseh, "Remember the word Moses the servant of Yhwh commanded you when he said: 'Yhwh your god is giving you rest, and he has granted this territory to you.' Let your wives, children, and livestock remain in the land that Moses gave you on this side of the Jordan; but as for you, you shall cross over as shock troops, all mighty warriors, in the vanguard of your brothers. You shall assist them until Yhwh has given your brothers rest, such as you have, and they too have taken possession of the land that Yhwh your god has given to them. Then you may return to the land on the east side of the Jordan, which Moses the servant of Yhwh assigned to you as your possession, and you may possess it." Josh. I:I2-I 5

As so often in the NTT, the eastern tribes affirm their commitment to obey the commandments issued by Moses and Joshua. Now, however, they announce that the death penalty awaits anyone who defies their orders:

They answered Joshua, "We will do everything you have commanded us and we will go wherever you send us. We will obey you just as we obeyed Moses; let Yhwh your god be with you as he was with Moses! Any man who flouts your commands and does not obey every order you give him shall be put to death. Be now strong and resolute!” Josh. I:I 6-I 8 
This lengthy episode of the NTT is easy to identify as a supplement to the book's older introduction in I:IO-II. ${ }^{4}$ Its presence at the very beginning of the book witnesses to the importance of the Transjordanian issue. It also obviates the need to interpolate multiple references to the eastern tribes throughout the narrative. Even so, several chapters later the narrator confirms that they crossed the Jordan in the vanguard of the nation. The second line underscores the large number of warriors who took part, yet instead of marching as a vanguard for the nation, they cross over "before Yhwh," as in the Priestly edition of Numbers 32 :

The Reubenites, the Gadites, and the half-tribe of Manasseh went across armed in the vanguard of the Israelites, as Moses had charged them. About forty thousand shock troops went across, before Yhwh, prepared for war in the steppes of Jericho. Josh. 4:I 2-I 3

The short passage may be the work of two different scribes, since the second line (v. I3), when read independently of the preceding line (v. I2), could be interpreted as referring to the number of Israelite troops in general. However, the formulations "shock troops" and "before Yhwh" appear frequently in reference specifically to the eastern tribes in our texts, and therefore it's more likely that the second line was composed at the same time as, or after, the first.

\section{THE DIVISION OF THE LAND}

At its core, the book of Joshua commemorates "the conquest" as the wars Joshua conducted in Canaan, i.e., in territories on the western side of the Jordan. As such, this work points up the absence of a corresponding book that celebrates the nation's triumphs in the Transjordan. To compensate for this absence, later scribes expanded the book with a number of prominent passages, such as the ones we discussed in the preceding section. We find other important supplements in the numerical accounts found in chapters I $2-\mathrm{I} 4$.

In keeping with the polemic against kingship in this work, the scribes drafted two registers of vanquished monarchs, the first relating to the conquests of Moses in the Transjordan (I2:I-6) and the second to the conquests of Joshua in the Cisjordan (I2:7-24). While the second

\footnotetext{
4 Pace Germany, Exodus-Conquest Narrative, 3I4-3I7, who argues for the priority of I:I-2. Joachim J. Kraus argues convincingly why I:I $7-I 8$ does not represent the response from the officials in I:IO-I I; see his Exodus und Eisodus: Komposition und Theologie von Josua I-5 (Leiden: Brill, 20I4), II7-I25. I discuss the development of this narrative in Part III.
} 
lists the names of thirty-one kings (explicitly tallied in the final line, v. 24b), the first consists of only two: Sihon and Og. These enumerations presuppose and systematize all the battles reported in the narrative up to this point, and an earlier edition of the book may have terminated here. We are told in I 2:7 that Joshua divided the conquered territories in the Cisjordan among "the tribes of Israel," and the formulation of the verse leaves the impression that its author did not have the other accounts of tribal allotments contained in the following chapters. Moreover, it seems reasonable to assume that a different scribe added the first list (recording the Transjordanian conquests) at a later point: I2:7 leaves the impression that all "the tribes of Israel" settled in the Cisjordan (see already I I:23); the first list ends, however, by reporting that "Moses, the servant of Yhwh, gave [the land] to the Reubenites, Gadites, and half-tribe of Manasseh as their possession" (v. 6). ${ }^{5}$

The latter half of Joshua, beginning in chapter $\mathrm{I}_{3}$, recounts the division of the land among the nation's twelve tribes. The narrator goes to great lengths to clarify that the conquered land was being divided solely among nine and a half tribes, since Moses had already assigned territories to two and a half tribes on the east side of the Jordan:

Now the Reubenites and the Gadites, along with the other half-tribe, had already received the shares which Moses assigned to them on the east side of the Jordan .... Josh. I $3: 8$

The remaining twenty-five verses of chapter I 3 describe precisely what lands the two-and-a-half tribes inherited collectively and then separately.

The first lines of chapter I 4 form what appears to be an older introduction to the following tribal registers, and it appears to have been expanded with a reminder that two and a half tribes had already received their territories from Moses. Notice how the italicized portion severs the sentence that frames it:

These are the allotments of the Israelites in the land of Canaan that were apportioned to them by the priest Eleazar, by Joshua son of Nun, and by the heads of the ancestral houses of the Israelite tribes. The portions were by lot. As Yhwh had commanded through Moses...

that is, for the nine and a half tribes, for the portion of the other two and a half tribes had been assigned to them by Moses on the other side of the Jordan. He had not assigned any portion among them to the Levites; for whereas the descendants of Joseph constituted two tribes, Manasseh and Ephraim, the Levites were

5 See the discussion in Thomas B. Dozeman, Joshua I-I 2: A New Translation with Introduction and Commentary (New Haven: Yale University Press, 20I 5), 482-500. 
assigned no share in the land, but only some towns to live in, with the pastures for their livestock and cattle. As Yhwh had commanded Moses

$\ldots$ so the Israelites did, and they apportioned the land. Josh. I4:I- $-5^{6}$

Aside from sporadic (secondary) references throughout the remaining registers, the next time we hear about the eastern tribes is in chapter 22, the final episode in the NTT. The account tells how these tribes, after serving alongside the Cisjordanian Israelites in battle, provoke the latter to rise up in arms against them. The casus belli is a massive altar that they had built near the Jordan. Deeming the construction to be "treachery" and potentially rivaling Yhwh's tabernacle, "the Israelites" mobilize for military action, planning to lay waste the Transjordanian territories. Because of its length and importance, this episode merits more attention.

\section{HONORING WARTIME SERVICE}

Joshua 22 describes little action, while devoting a lot of space to verbal exchanges. In this respect, the authors adopted the same narrative strategy as employed in Numbers 32 . In each case, representatives of Israel begin with lengthy indictments that appeal to key moments in the nation's past. ${ }^{7}$

The account begins inauspiciously with the nation's leader summoning the eastern tribes for the purpose of discharging them to their homes across the Jordan. As he does, he pays tribute to their exemplary wartime contributions during the conquest, commending them for their obedience and allegiance:

Then Joshua summoned the Reubenites, the Gadites, and the half-tribe of Manasseh, and said to them, "You have observed all that Moses the servant of Yhwh commanded you, and have obeyed me in everything that I commanded you. You have not forsaken your brothers these many days indeed to this very day - but have faithfully kept the charge of Yhwh your god. Now Yhwh your god has given rest to your brothers, as he promised them. You may therefore return to your homes, to the land of your holdings beyond the Jordan that Moses the servant of Yhwh assigned to you. But be very careful to fulfill the commandment and teaching of Moses, the servant of Yhwh: to love Yhwh your god and to walk in all his ways, and to keep his

${ }^{6}$ This smaller expansion in chapter I4 likely preceded the larger insertions in chapter I3. The redundancy here would have been necessitated by the composition of a new introduction in I3:I-7. The latter ends with a reference to the nine and a half tribes that may have elicited the lengthy excursus in $13: 8-33$.

7 The translation of Joshua 22 in what follows is adapted from the JPS (I986) version. For a helpful approach to the chapter, see Elie Assis, "For It Shall Be a Witness Between Us: A Literary Reading of Josh 22," Scandinavian Journal of the Old Testament, I8 (2004), 208-23I. 
commandments and hold fast to him, and to serve him with all your heart and soul." Then Joshua blessed them and dismissed them, and they went to their homes. Josh. 22:I-6

According to Joshua's evaluation, the tribes have fulfilled their military obligations during the conquest of Canaan. In the opening chapter of the book, he reminded them of Moses's commands, and here he commends them for both heeding those orders and fulfilling their duty to their brethren. As they now prepare to return to their homes across the Jordan, Joshua enjoins them to continue to heed the charge they had received from Moses, which has been reformulated in Deuteronomistic diction: They must love Yhwh their god, walk in all his ways, keep his commandments, and serve him with heart and soul. The profusion of these tropes affirms devotion to Yhwh and the Torah as the foundation of Israel's national identity, especially for them as members of communities residing beyond the nation's borders. What's notable is how the address connects this theme of law to kinship: the Transjordanians demonstrated their fidelity to Yhwh's law by contributing to a war effort for their Cisjordanian "brothers."

Before departing and leaving "the Israelites" in the land of Canaan, the eastern tribes receive unexpected and rich rewards for their service:

Furthermore, when Joshua sent them off to their homes, he blessed them and said to them, "Return to your homes with great wealth - with very much livestock, with silver and gold, with copper and iron, and with a great quantity of clothing. Share the spoil of your enemies with your brothers."

So the Reubenites, the Gadites, and the half-tribe of Manasseh left the Israelites at Shiloh, in the land of Canaan, and made their way back to the land of Gilead, the land of their own holding, which they had acquired by the command of Yhwh through Moses. Josh. 22:7b-9

The first versions of this account likely concluded with this joyous farewell. ${ }^{8}$ Providing a beautiful example of biblical war commemoration, the authors of the NTT have called attention here, one last time, to the service rendered by the eastern tribes during the conquest of Canaan.

${ }^{8}$ Originally, this first part may have consisted only of 22:I-6, which concludes with the tribes returning to their homes; if so, verse 7 a would be an early addition to the conclusion before the composition of verses $7 \mathrm{~b}-9$. Whatever the case may be, with its emphasis on obedience to Moses and fulfillment of fraternal obligations, all of 22:I-9 has the same tenor as the older version of Numbers 32 and the Deuteronomistic parts of the NTT, while the continuation in verses Io-34 is consonant with the Priestly reworking of Numbers 32 . 
FROM CELEBRATION TO CRISIS

The lengthy continuation (22:10-34) is easy to recognize as a later composition. While verses I-9 are loaded with the lexicon of Deuteronomy, this second part has a pronounced Priestly imprimatur and portrays a dramatic shift from celebration to crisis.

On their way home, the eastern tribes build an altar by the Jordan. Its construction provokes outrage among the Israelites, who prepare to wage war against them:

When they came to the region of the Jordan in the land of Canaan, the Reubenites, Gadites, and half-tribe of Manasseh built an altar there by the Jordan, a great and conspicuous altar. A report reached the Israelites: "The Reubenites, Gadites, and half-tribe of Manasseh have built an altar opposite the land of Canaan, in the region of the Jordan, across from the Israelites." When the Israelites heard this, the whole congregation of the Israelites assembled at Shiloh to make war on them. Josh. 22:IO-I 2

Gathering at the holy city of Shiloh, the Israelites decide first to dispatch emissaries to the Transjordan. Just like Moses in the first episode of the NTT (Num. 32), the delegation doesn't wait for an explanation and launches an elaborate excoriation that appeals to the nation's past:

The Israelites sent Phinehas ben Eleazar, the priest, to the Reubenites, Gadites, and half-tribe of Manasseh in the land of Gilead, accompanied by ten chieftains, one chieftain from each ancestral house of each of the tribes of Israel; they were every one of them heads of ancestral houses of the contingents of Israel. When they came to the Reubenites, Gadites, and half-tribe of Manasseh in the land of Gilead, they spoke to them as follows:

"Thus saith all the congregation of Yhwh: 'What is this treachery that you have committed this day against the god of Israel, turning away from Yhwh by building yourselves an altar and rebelling this day against Yhwh! Is the sin of Peor, which brought a plague upon the community of Yhwh, not enough for us? To this very day we have yet to cleanse ourselves from it. And now you would turn away from Yhwh! If you rebel against Yhwh today, tomorrow he will be angry with all the congregation of Israel.

"If it is because the land of your holding is unclean, cross over into the land of Yhwh's own holding, where the tabernacle of Yhwh dwells, and acquire holdings among us. But do not rebel against Yhwh, and do not rebel against us by building for yourselves an altar other than the altar of Yhwh our god. When Achan son of Zerah violated the proscription, anger struck the whole community of Israel; he was not the only one who perished for that sin.'” Josh. 22:13-20

When the accused are finally allowed to speak, they protest even more vigorously than they did in Numbers 32, insisting that they have, once again, been misunderstood. Instead of a place for sacrifices that would 
compete with Yhwh's one true altar, they constructed this replica to serve as a memorial witnessing to future generations:

The Reubenites, Gadites, and half-tribe of Manasseh replied to the heads of the contingents of Israel. They said, "God, Yhwh God! God, Yhwh God! He knows, and Israel too shall know! If we acted in rebellion or in treachery against Yhwh, do not vindicate us this day! If we built an altar to turn away from Yhwh, if it was to offer burnt offerings or meal offerings upon it, or to present sacrifices of well-being upon it, may Yhwh himself demand a reckoning.

"To the contrary: we did this thing only out of our concern that, in time to come, your children might say to our children, 'What have you to do with Yhwh, the god of Israel? Yhwh has made the Jordan a boundary between you and us, O Reubenites and Gadites! You have no share in Yhwh.' In such ways your children might prevent our children from worshiping Yhwh.

"So we decided to provide a witness for ourselves by building an altar - not for burnt offerings or other sacrifices, but as a witness between you and us, and between the generations to come - that we may perform the service of Yhwh before him with our burnt offerings, our sacrifices, and our offerings of well-being; and that your children should not say to our children in time to come, 'You have no share in Yhwh.'

"We reasoned: should they speak thus to us and to our children in time to come, we would reply, 'See the replica of Yhwh's altar, which our fathers made - not for burnt offerings or sacrifices, but as a witness between you and us.' Far be it from us to rebel against Yhwh, or to turn away this day from Yhwh and build an altar for burnt offerings, meal offerings, and sacrifices other than the altar of Yhwh our god that stands before his tabernacle." Josh. 22:2I-29

As in Numbers 32, the remonstration of the eastern tribes absolves them of any wrongdoing in the eyes of their accusers. The delegation responds by declaring that they now know that Yhwh is in their midst and that these tribes had, in fact, "saved the Israelites" - not from their Canaanite foes, as these tribes had done before, but from their own god, who was about to punish the nation:

When the priest Phinehas and the chieftains of the community - the heads of the contingents of Israel - who were with him heard the explanation given by the Reubenites, Gadites, and Manassites, they approved. The priest Phinehas son of Eleazar said to the Reubenites, Gadites, and Manassites, "Now we know that Yhwh is in our midst, since you have not committed such treachery against Yhwh. You have indeed saved the Israelites from punishment by Yhwh.” Josh. 22:30-3 I

The emissaries then return to "the Israelites in Canaan," and after hearing their report, the Israelites relinquish their plans for punitive action against the land occupied by the tribes:

Then the priest Phinehas son of Eleazar and the chieftains returned from the Reubenites and Gadites in the land of Gilead to the Israelites in the land of 
Canaan and gave them their report. The Israelites were pleased, and the Israelites praised God; and they spoke no more of going to war against them to ravage the land in which the Reubenites and Gadites dwelt.

The Reubenites and Gadites named the altar ["Witness"], meaning, "It is a witness between us and them that Yhwh is [our] god." Josh. 22:32-34

In the end, a civil war is avoided, but the reader is left wondering: What exactly is the relationship between the Israelites and the Transjordanian tribes?

\section{NATION VERSUS TERRITORY}

The first thing to notice about this final episode in the NTT is that it insinuates that the Transjordan does not belong to Israel's god and is (ritually) unclean. In the first section of the chapter, which celebrates the Transjordanians' contributions, the territory of the eastern tribes is designated as the land of their "holding" ('ahuzzāh; see vv. 4, 9). This technical term refers to territory they receive from Yhwh as an award for their military service, as reiterated throughout Numbers 32 . In contradistinction to these texts, Phinehas asserts in this polemical account that if the eastern tribes consider the land they "hold" to be "unclean/defiled" $(t \bar{a} m \bar{e})$, they should cross the Jordan and take up residence in "the land of Yhwh's own holding, where the tabernacle of Yhwh dwells, and acquire holdings among us" (v. I9, emphasis added; cf. Num. 32:30).

At the beginning of the account, we are told that the altar stood "opposite the land of Canaan, in the region of the Jordan, across from the Israelites" (v. I I). Similarly, when the tribes explain their motivation for building an altar near the Jordan, they mention the fear of discrimination and exclusion for future generations: "In time to come your children might say to our children, 'What have you to do with Yhwh, the god of Israel? For Yhwh has made the Jordan a boundary between you and us, O Reubenites and Gadites!'” (vv. 24-25). We learn in the conclusion that the Israelites were preparing "to ravage the land in which the Reubenites and Gadites dwelt" (v. 33, emphasis added). ${ }^{9}$

9 This military aggression is reminiscent not only of the war conducted by the Israelite tribes against Benjamin in Judges 20-2I, but also of the Sacred Wars fought by the Amphictyonic League in defense of the sanctuary at Delphi $(600-590,448,355-346,339-338 \mathrm{BCE})$. The destruction of the land in our account is noteworthy since the belligerents in the Sacred Wars focused their aggression against the land as well; the laws of the league explicitly addressed these ecocidal tendencies. On the subject of ecocide, see Jacob L. Wright, 
From these and similar statements, we see how the account distinguishes between the country east of the Jordan, which may be just as unclean as other foreign lands, on the one hand, and the communities living in that country who belong to the people of Israel, on the other hand. ${ }^{10}$ The nation is therefore larger than, and transcends, its territorial borders.

Although the Transjordanians are distinguished from the Israelites in this account, their offenses have direct ramifications for the welfare of the nation as a whole. In setting forth their charges, Phinehas and the tribal chiefs compare the sin in building the altar to the transgressions of Peor (Num. 25). Aside from reminding the reader of the debacle that occurred in what became the territory of Reuben, the point seems to be that the sin of one member brings punishment upon all members. As noted with respect to Moses's accusations in Numbers 32, the comparison does more than simply inculpate the Transjordanians; it identifies them as fullfledged members of the nation. Israelites in the Cisjordan must concern themselves with the actions of these Transjordanian communities (who are not called "Israelites") because they have direct implications for their own well-being: "If you rebel against Yhwh today, he will be angry with the entire congregation of Israel tomorrow" (v. I 8).

A similar point is made by the intrabook reference to the sin of Achan after the battle of Jericho: "Did not Achan ben Zerah break faith in the matter of the devoted things, and wrath fall upon the whole congregation of Israel? He did not perish alone for his iniquity!" (v. 20). The account of Achan's transgressions in Joshua 7 is a tale of collective responsibility, the punishment of the entire community for the sin of one of its members. As the sociologist Émile Durkheim observed, the problems presented by collective punishment pertain ultimately to larger questions of belonging, and they have extraordinary pedagogical potential inasmuch as they provoke reflection on "the ties that bind" and the mutual obligations that shape a community's identity. In the various ways societies confront

\footnotetext{
"Warfare and Wanton Destruction: A Reexamination of Deuteronomy 20:19-20 in Relation to Ancient Siegecraft," Journal of Biblical Literature, I 27 (2008), 423-458.

Io For use of the expression "unclean lands" in reference to foreign lands, see Amos 7:I7; Hosea 9:3-5; Zech. 2:I6. Baruch Levine makes a good case that the original formulation of the passage did not present the altar as being built west of the Jordan (Numbers $21-36$ [New York: Doubleday, 2000], 505). Notice, for example, how the multiple clauses in verse II, which appear to be glosses, define the location of the altar. Moreover, the uncleanness of the Transjordan is underscored in what appear to be the same literary layers that (re-)locate the altar in Canaan.
} 
these problems, they express competing ideals of communal solidarity and social cohesion. ${ }^{\mathrm{II}}$ The case of Achan dovetails with the larger concerns in this account raised by the Transjordanians' relationship to the Cisjordanians. By asserting that their actions will bring judgment on all Israel, the emissaries identify the eastern tribes as integral parts of the nation. ${ }^{\mathrm{I} 2}$

With respect to the altar itself, the eastern tribes repeatedly insist that they did not build it to be used for actual sacrifices or offerings - although their statement in verse 27 is confusing. As a replica of Israel's one and only divinely sanctioned altar that stood before the tabernacle, it was to serve as a monument reminding future generations that the communities on the eastern side of the Jordan "have a portion in Yhwh."

The account not only witnesses to a conflict over the status of the populations in the Transjordan, and to the existence of groups in the Cisjordan who argued that Yhwh made the Jordan a boundary to the land of Israel. It also shows that some factions in this dispute (such as the authors of our text) appealed to Yhwh veneration as the basis for this unity. Such veneration, our account argues, must honor the one divinely sanctioned altar, which was part of the tabernacle before being erected in Jerusalem. The eastern tribes had thus built a memorial in the likeness of the nation's physical point of unity.

\section{ONE YHWH, ONE ISRAEL}

Our text belongs to a program of national unification and cult centralization that produced the foundational creed for Israel's corporate identity: "Hear O Israel, Yhwh is our god, Yhwh is one!" (Deut. 6:4). By proclaiming the unity of the various Yhwhs worshiped in diverse communities, this groundbreaking declaration laid the theological and cult-historical cornerstone for efforts to transcend political and territorial differences in favor of national unity: One Yhwh, one Israel. ${ }^{\mathrm{I}}$

${ }^{I}$ Émile Durkheim, Moral Education: A Study in the Theory and Application of the Sociology of Education (New York: Free Press, 1973), originally published as L'éducation morale (Paris: Librairie Félix Alcan, I925).

${ }^{12}$ Notice that also in Phinehas's final statement (v. $3 \mathrm{I}$ ) the actions of the eastern tribes determine the fate of Israel.

I3 On the unification of Yhwhs by this text, see Jeremy M. Hutton, "Local Manifestations of Yahweh and Worship in the Interstices: A Note on Kuntillet 'Ajrud," Journal of Ancient Near Eastern Religions, Iо (2010), I77-2 IO. On deities worshiped by Iron Age communities that affirmed affiliation to Israel, see Hutton, "Southern, Northern, and 
The same goes for the identification of other deities with Yhwh. Abundant archeological evidence reveals that the cults of El, Elyon, Shaddai, and other deities were more deeply rooted in the Transjordan than that of Yhwh. The composition histories of the Balaam account, the Elijah cycle, and other biblical texts witness to a redactional process by which these deities came to be identified with Yhwh, with their names now being understood as alternative designations for this deity. ${ }^{\mathrm{I}}$

In past scholarship, the unification of Yhwh worship and the identification of other deities with Yhwh has, for the most part, been treated as a preexilic, Iron Age phenomena. However, this theological-political project continued to be pertinent in the postexilic period, when Jerusalem competed with communities in Samaria, the Transjordan, and elsewhere. In Joshua 22, the Transjordanians finish their retort by affirming their allegiance to the one altar of "Yhwh, our god." In the final line of the account, they name the altar "Witness," because "it is a witness between us that Yhwh is God" (v. 34). The altar here represents not only fidelity to the nation's one god but also cultic unity. We saw how the first part of the chapter, where Joshua celebrates the contributions of the eastern tribes, emphasizes love for Yhwh and his commandments. By contrast, the second part introduces a crisis as a way of championing the cause of priests in Jerusalem, for whom worship at Yhwh's one altar was the condicio sine qua non of Torah observance.

In his Memoir from the mid-fifth century BCE, Nehemiah reports that the family of a prominent Transjordanian figure named Tobiah had not only intermarried with priests in Jerusalem but also possessed a pied-àterre in the temple precincts there (see esp. Neh. I3:4-9). On the basis of this text, some scholars claim that Tobiah - whose name expresses devotion to Yhwh - may have worshiped at Jerusalem and that he recognized the altar there to be the only authorized one. If so, he would have adhered to the priestly expectations expressed in the second half of Joshua 22. ${ }^{15}$

Transjordanian Perspectives” in Francesca Stavrakopoulou and John Barton (eds.), Religious Diversity in Ancient Israel and Judah (London: Continuum, 2010), I49-I74.

${ }^{14}$ On the identification of deities, see Mark Smith, The Early History of God (Grand Rapids: Eerdmans, 2002); Smith, The Memoirs of God (Minneapolis: Fortress Press, 2004); Smith, God in Translation (Tübingen: Mohr Siebeck, 2008). Smith draws on Jan Assmann's notion of translatability set forth in, inter alia, Moses the Egyptian: The Memory of Egypt in Western Monotheism (Cambridge, MA: Harvard University Press, I 997). See also Benjamin D. Sommer's notion of fluidity and fragmentation in The Bodies of God and the World of Ancient Israel (Cambridge: Cambridge University Press, 2009).

I5 See, e.g., Ulrike Schorn, Ruben und das System der zwölf Stämme Israels (Berlin: De Gruyter, I997); Ronnie Goldstein, "Joshua 22:9-34: A Priestly Narrative from the 
It's noteworthy that this Transjordanian figure is Nehemiah's archnemesis. (When Nehemiah arrives in Jerusalem, the first thing he does is expel Tobiah from the temple precincts.) In the Judah-centric program promoted by the Nehemiah Memoir, religious devotion to Yhwh has little meaning in and of itself; what's more important is that the people of Judah develop a sense of kinship and practice the special obligations that ensue from it. In Chapter 6, we conclude Part II by considering the role of kinship in relation to law and narrative.

Second Temple Period," Shnaton, I3 (2002), 43-8 I [in Hebrew]. On Neh. I3:4-9, see my analysis in Rebuilding Identity, I9I-203. 